\title{
KARAKTER MORFOMETRIK PENSI (Corbicula moltkiana Prime) PADA DUA EKOSISTEM YANG BERBEDA
}

\author{
Armein Lusi Zeswita*, Elza Safitri \\ Program Studi Pendidikan Biologi Sekolah Tinggi Keguruan dan Ilmu \\ Pendidikan (STKIP) PGRI Sumatera Barat
}

(Diterima Agustus 2015, Disetujui Oktober 2015)

\begin{abstract}
Lake Maninjau and Batang Antokan is a place that used as recreation and tourism spots in Agam District. Both human activities around the lake or on river affect the water quality, both in physics and chemistry, and biology, and greatly affect the lives of shellfish. Given the high activity of catching "Pensi" Corbicula moltkiana on Lake Maninjau, it is necessary to attempt to preserve shellfish populations and to seek ways of cultivation so that utilization can be continuously and can improve the community economy. This study aims to determine the morphometric characters Pensi (Corbicula moltkiana Prime) in two different ecosystems and Physical-chemical factors that influence it. This study had been done in February 2015 at Lake Maninjau and in Sungai Batang Antokan. Based on research at Lake Maninjau and in Sungai Batang Antokan size of shell such as length, height, width, length hinge, the amount of lines and heavy wet growth in Batang Antokan pensi meat more variable when compared to Lake Maninjau. However, the size of the shell length performs in Batang Antokan different with in Lake Maninjau while the size of the width and weight of wet meat Pensi is no different in the two habitats. The relationship between the length of the wet weight of the meat at Lake Maninjau and in Batang Antokan correlate very closely with their clam shell length. Chemical physics factors of water in Lake Maninjau and in Batang Antokan still within the normal range and tolerant in Pensi (Corbicula moltkiana Prime) life support except levels of organic substrate.
\end{abstract}

Keyword : Corbicula moltkiana, morphometric, shell

\begin{abstract}
ABSTRAK
Danau Maninjau dan Batang Antokan adalah tempat yang digunakan untuk rekreasi dan pariwisata di Kabupaten Agam. Kedua aktivitas manusia di sekitar danau atau di sungai mempengaruhi kualitas air, baik dalam fisika dan kimia, dan biologi, dan sangat mempengaruhi kehidupan kerang. Mengingat aktivitas tinggi menangkap "Pensi" Corbicula moltkiana di Danau Maninjau, perlu untuk mencoba untuk melestarikan populasi kerang dan mencari cara budidaya sehingga pemanfaatan yang terus menerus dan dapat meningkatkan perekonomian


masyarakat. Penelitian ini bertujuan untuk mengetahui karakter morfometrik Pensi (Corbicula moltkiana Prime) di dua ekosistem yang berbeda dan faktor fisik-kimia yang mempengaruhinya. Penelitian ini telah dilakukan pada bulan Februari 2015 Danau Maninjau dan di Sungai Batang Antokan. Berdasarkan penelitian di Danau Maninjau dan di Sungai Batang Antokan ukuran cangkang seperti panjang, tinggi, lebar, panjang engsel, jumlah baris dan pertumbuhan basah berat di Batang Antokan daging pensi lebih bervariasi bila dibandingkan dengan Danau Maninjau. Namun, ukuran panjang cangkang melakukan di Batang Antokan berbeda dengan di Danau Maninjau sedangkan ukuran lebar dan berat daging basah Pensi tidak berbeda dalam dua habitat. Hubungan antara panjang berat basah daging di Danau Maninjau dan Batang Antokan di berkorelasi sangat erat dengan panjang clam shell mereka. Faktor fisika kimia air di Danau Maninjau dan Batang Antokan di masih dalam kisaran normal dan toleran di Pensi (Corbicula moltkiana Perdana) mendukung kehidupan kecuali tingkat substrat organik

Katakunci: Corbicula moltkiana, morfometrik, kerang

\section{PENDAHULUAN}

Corbicula moltkiana Prime merupakan jenis kerang yang dikenal oleh masyarakat Sumatera Barat dengan nama pensi, tergolong famili Corbiculidae. Corbicula merupakan kerang khas air tawar yang bernilai ekonomis. Kerang air tawar ini dikonsumsi masyarakat sebagai sumber protein hewani, digunakan sebagai bahan pakan ternak. Jenis kerang ini hidup didasar perairan yang berlumpur, berpasir dan substrat yang lebih keras (Suwignyo, Widigdo, Wardiatno dan Krisanti, 2005).

Danau Maninjau merupakan salah satu danau yang dijadikan tempat rekreasi dan pariwisata di Kabupaten Agam. Selain itu, di sekitar Danau ini juga dimanfaatkan sebagai tempat pemukiman penduduk. Di Danau Maninjau banyak didapatkan pensi yang dimanfaatkan oleh masyarakat sebagai makanan cemilan yang khas bagi para pengunjung pariwisata yang berekreasi. Keberadaan pensi di Danau Maninjau merupakan anugerah bagi masyarakat sekitarnya, dimana dengan keberadaan pensi secara tidak langsung dapat menunjang perekonomian penduduk sekitar danau. Masyarakat di sekitar Danau Maninjau mengambil pensi hampir setiap hari secara langsung dari habitatnya.

Kerang air tawar cocok sebagai organisme indikator yang mana keberadaannya di suatu perairan dapat digunakan untuk mengukur kondisi lingkungan di sekitarnya. Karena kerang air tawar memiliki karakter yang khas 
diantaranya masa hidup yang panjang, fase muda (juvenile) dan dewasa bersifat immobile serta bersifat filter feeder (menyaring air untuk mengambil makanan) (Grabarkiewichz dan Wayne, 2008 dalam Ramadhani, Affandi dan Irawan, 2011). Mengingat peran penting kerang air tawar dalam ekosistem dan besarnya ancaman terhadap kepunahan kerang ini, maka penting diadakan upaya konservasi terhadap populasi kerang ini. Untuk mendukung upaya tersebut tentu dimulai dari kajiankajian berbagai aspek dari kerang ini dan salah satunya adalah kajian tentang ekologisnya diantaranya mengetahui distribusi ukuran cangkang, faktor fisika kimia dan biologi lingkungan yang mendukung kehidupannya, tekstur dan kandungan bahan organik substrat pada habitat kerang ini hidup. Penangkapan kerang yang terus menerus tanpa memperhitungkan aspek ekologinya tentu akan dapat mengancam dan menurunkan populasi kerang didanau ini.

Mengingat tingginya aktivitas penangkapan pensi Corbicula moltkiana Prime di Danau Maninjau, maka perlu dilakukan upaya untuk melestarikan keadaan populasi kerang ini dan mengupayakan cara pembudidayaannya sehingga pemanfaatannya dapat berkesinambungan dan dapat meningkatkan perekonomian masyarakat. Untuk itu penulis telah melakukan penelitian dengan judul "Karakter Morfometrik Pensi (Corbicula moltkiana Prime) Pada Dua Ekosistem Yang Berbeda".

\section{BAHAN DAN METODE}

Pengambilan sampel Corbicula moltkiana Prime di DanauManinjau dan di Sungai Batang Antokan telah dilaksanakan pada bulan Februari 2015.Pengukuran karakter morfometrik dilakukan di Laboratorium Dasar Program Studi Pendidikan Biologi STKIP PGRI Sumatera Barat. Uji kadar kalsium dan DO dilakukan di Laboratorium Bapelkes Gunung Pangilun Padang. Pengukuran kadar organic substrat dilakukan di Laboratorium Fisika Kimia Tanah Fakultas Pertanian UniversitasAndalas. Alat yang digunakan adalah sampan, ember, label tempel, kamera digital, thermometer $\mathrm{Hg}$, botol sampel air ukuran $150 \mathrm{ml}$, kertas indikator $\mathrm{pH}$, kantong plastik, neraca digital (timbangan), caliper, kaca arloji, kater, pinset dan alat-alat tulis. Bahan yang di gunakan adalah tissu, $\mathrm{MnSO}_{4}$, 
$\mathrm{H}_{2} \mathrm{SO}_{4}$ pekat, $\mathrm{KOH} / \mathrm{KI}, \mathrm{Na}_{2} \mathrm{~S}_{2} \mathrm{O}_{3}$ 0,025, larutan amilum $1 \%$ dan pensi (Corbicula moltkiana Prime).

Penelitian dilakukan menggunakan metode survey deskriptif, dengan teknik observasi lapangan yaitu pengamatan langsung dan pengambilan sampel secara Sequential Sampling, yaitu dengan cara pengambilan sampel pensi sampai jumlah yang diinginkan tercapai. Analisis data dilakukan dengan cara Hubungan antara ukuran cangkang (panjang, tinggi dan tebal/lebar) dengan berat basah daging pensi (Corbicula moltkiana Prime) dianalisis dengan regresi liniear sederhana yaitu dengan model : $\mathrm{Y}=\mathrm{a}+\mathrm{bx}$ (Irianto, 2004).Dan dilanjutkan dengan analisa Uji t, dengan menggunakan rumus:

$t=\frac{\bar{x}_{1}-\bar{x}_{2}}{\sqrt{\frac{s 1}{n_{1}}+\frac{s 2}{n_{2}}}}$ uji siknifikan dengan $\mathrm{n}>30$ (Michael, 1998)

\section{HASIL DAN PEMBAHASAN}

Berdasarkan Tabel 1 diatas pensi yang berada di Sungai Batang Antokan memiliki ukuran yang lebih besar dibandingkan dengan yang di Danau Maninjau. Hal ini terlihat pada ukuran panjang cangkang, tinggi, lebar, panjang hinge dan berat basah daging. Berdasarkan analisis uji siknifican t pada 2 karakter morfologi dan berat basah, pada karakter panjang memperlihatkan perbedaan ukuran antara pensi di sungai dan di danau $\left(t_{\text {hit }}=3,31\right)$ sementara ukuran lebar dan berat basah tidak memperlihatkan perbedaan yang nyata antara pensi di sungai dan di danau $\left(t_{\text {hit }}=1,97 ; t_{\text {hit }}=1,36\right)$. Perbedaan ukuran cangkang pensi dipengaruhi oleh jenis substratnya. Substrat yang ditemukan di Danau Maninjau adalah substrat tanah berlumpur dan airnya agak keruh serta adanya sampah yang berserakan sebagai akibat aktivitas masyarakat dikarenakan lokasi merupakan pemukiman penduduk. Di Sungai Batang Antokan substratnya berpasir dan berbatu, dengan air yang jernih dan berarus deras serta lokasi yang jauh dari pemukiman penduduk. 
Tabel 1.Kisaran Ukuran Panjang, Tinggi, Lebar, Panjang Hinge, Jumlah Garis Pertumbuhan dan Berat Basah Daging Corbicula moltkiana Prime yang terdapat di danau Maninjau dan di Sungai Batang Antokan Kabupaten Agam.

\begin{tabular}{|c|c|c|c|}
\hline No. & Parameter & $\begin{array}{c}\text { Danau } \\
\text { Maninjau }\end{array}$ & $\begin{array}{c}\text { Sungai } \\
\text { Batang } \\
\text { Antokan }\end{array}$ \\
\hline 1 & $\begin{array}{l}\text { Panjang } \\
(\mathrm{mm})\end{array}$ & $16,1-22,6$ & $16,4-24,1$ \\
\hline 2 & $\begin{array}{l}\text { Tinggi } \\
(\mathrm{mm})\end{array}$ & $12,1-18,2$ & $12,1-18,3$ \\
\hline 3 & $\begin{array}{l}\text { Lebar } \\
(\mathrm{mm})\end{array}$ & $9,1-12,2$ & $8,1-14,2$ \\
\hline 4 & $\begin{array}{l}\text { Panjang } \\
\text { Hinge } \\
(\mathrm{mm})\end{array}$ & $4,1-7,1$ & $4,2-8,1$ \\
\hline 5 & $\begin{array}{l}\text { Jumlah } \\
\text { Garis } \\
\text { Pertumbuh } \\
\text { an (garis) }\end{array}$ & $15-24$ & $14-21$ \\
\hline 6 & $\begin{array}{l}\text { Berat } \\
\text { Basah } \\
\text { Daging (g) }\end{array}$ & $0,16-0,52$ & $0,18-0,69$ \\
\hline
\end{tabular}

Sinclair dan Isom, (1963) dalam Zeswita, (1999) menjelaskan bahwa bentuk dan warna cangkang dipengaruhi oleh umur, makanan, dan faktor lingkungan seperti perairan yang kotor dengan substrat yang berlumpur. Pada perairan yang kotor cangkang cenderung berukuran lebih kecil dan berwarna gelap, sedangkan pada perairan yang bersih dan substrat berpasir cangkang cenderung memiliki ukuran yang besar dan berwarna terang.

Faktor abiotik juga mendukung kehidupan bivalvia di perairan. Seperti suhu, oksigen terlarut (DO), pH, kadar Ca, kadar organic substrat. Mengacu pada Kordi (2011), kehidupan kerang juga di pengaruhi oleh suhu, suhu optimal untuk pertumbuhan yang baik dengan toleransi suhu berkisar $25-32^{\circ} \mathrm{C}$. Suhu air pada Danau Maninjau $28^{\circ} \mathrm{C}$ dan di Sungai Batang Antokan $29^{\circ} \mathrm{C}$, suhu di Danau dan di sungai ini masih termasuk dalam batas toleransi yang mempengaruh ikehidupan bentos ini, sehingga masih bisa bertahan hidup dan berkembang biak. Nilai derajat keasaman $(\mathrm{pH})$ di Danau Maninjau adalah 7 dan di Sungai Batang Antokan adalah 7. Hal ini sependapat dengan penelitian Zeswita (1999) derajat keasaman $(\mathrm{pH})$ Danau Maninjau berkisar antara 6,88-7,40. Menurut Okland, (1980),cit. Dermott, (1985) bahwa Mollusca akan sensitif pada pH yang kurang dari 5. Berdasarkan 
hal tersebut derajat keasaman perairan Danau Maninjau dan Sungai Batang Antokan menyokong keberadaan kehidupan hewan bentos ini.

Hasil uji kadar Kalsium (Ca), berdasarkan hasil uji sampel air di Laboratorium Bapelkes Gunung Pangilun Padang dengan Metode Detection Limits didapatkan kadar Ca di Danau Maninjau berkisar 2,162 mg/L dan di Sungai Batang antokan berkisar 5,26 mg/L. Sementara dari penelitian Zeswita, (1999) kadar Ca Danau Maninjau berkisar antara 8,49-9,00 mg/L.

Hasil pengukuran oksigen terlarut (DO), berdasarkan hasil uji sampel air di Laboratorium Bapelkes Gunung Pangilun Padang didapatkan DO Danau Maninjau berkisar antara 4,50 mg/L dan Sungai Batang Antokan berkisar antara $5,26 \mathrm{mg} / \mathrm{L}$. Sementara dari penelitian Zeswita, (1999) kadar oksigen terlarut (DO) di Danau Maninjau berkisar antara 8,48-9,60 mg/L. Mengacu pada Kordi (2011), pertumbuhan biota laut terjadi pada lingkungan perairan dengan kandungan oksigen $4 \mathrm{mg} / \mathrm{L}$. Sedangkan kandungan optimumnya adalah antara 5-6 mg/L, dan kerang memiliki toleransi kebutuhan oksigen 3-6 mg/L. Berdasarkan hal tersebut kadar oksigen di Sungai Batang Antokan berada pada kondisi optimum dibandingkan dengan di Danau Maninjau.

Hasil pengukuran Kadar Organik Substrat (KOS), berdasarkan hasil uji sampel substrat di Laboratorium Fisika Kimia Tanah Fakultas Pertanian Universitas Andalas didapatkan kandungan substrat di Danau Maninjau sebesar 0,5\% dan di Sungai Batang Antokan sebesar 0,18\%. Sementara dari penelitian Zeswita, (1999) kadar organik substrat Danau Maninjau berkisar antara 3,74-4,5 $\%$. Persentase kadar organic substrat dikelompokkan kedalam 5 kategori yaitu sangat rendah untuk < 1; rendah untuk C (\%) berkisar antara 1,00-2,00; sedang untuk C (\%) berkisar antara 2,01-3,00; tinggi untuk C (\%) berkisar antara 3,015,00; sangat tinggi untuk C (\%) berkisar > 5,00 (Safriansyah, 2010). Berdasarkan hal tersebut kadar organic subtrat Danau Maninjau dan Sungai Batang Antokan dikategorikan sangat rendah. 
1. Hubungan Ukuran Panjang Cangkang dengan Berat Basah Daging Pensi

Berdasarkan pada Gambar 1 nilai koefisien persamaan dari regresi linier sederhana Danau Maninjau yaitu $\mathrm{Y}=18,98+12,96 x$ dapat diartikan bahwa nilai konstanta (a) sebesar 18,98 menyatakan berat basah daging sebelum dipengaruhi panjang cangkang dan nilai koefisien regresi

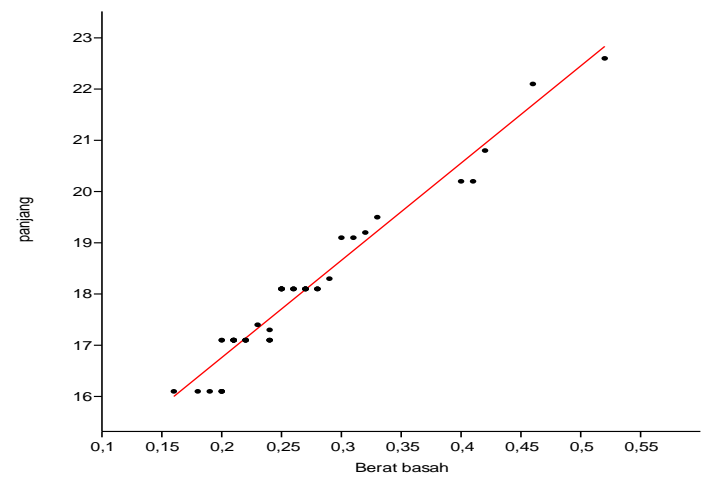

Gambar 1. Hubungan berat basah daging pensi dengan panjang cangkang pensi di Danau Maninjau Kec.Tanjung Raya Kab.Agam ( $Y=18,98+12,96$ X; r = 0,975)

dari variabel (b) panjang cangkang sebesar 12,96 yang bertanda positif menunjukkan terjadinya pengaruh positif panjang cangkang terhadap berat basah daging, semakin panjang ukuran cangkang maka semakin bertambah pula berat basah daging sesuai dengan pertumbuhan dan pertambahan panjang cangkang. Selanjutnya nilai koefisien korelasi $\mathrm{r}$ berkisar 0,975 yang berarti menunjukkan besarnya pengaruh panjang cangkang terhadap berat basah daging yaitu sebesar 97,5 \% dan sisanya $2,5 \%$ berat basah daging yang dipengaruhi oleh variabel lain selain panjang cangkang (Irianto, 2004). 


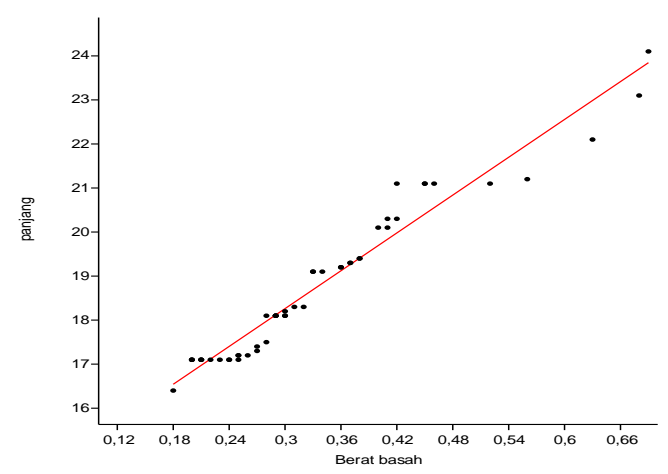

Gambar 2. Hubungan berat basah daging pensi dengan panjang cangkang pensi di Sungai Batang Antokan Kec. Lubuk Basung Kab. Agam( $\mathrm{Y}=14,32+13,97 \mathrm{X} ; \mathrm{r}=0,975$ )

Berdasarkan pada Gambar 2 nilai koefisien persamaan dari regresi linier sederhana Sungai Batang Antokan yaitu $\mathrm{Y}=14,32+13,97 \mathrm{x}$ dapat diartikan bahwa nilai konstanta (a) sebesar 14,32 menyatakan berat basah daging sebelum dipengaruhi panjang cangkang dan nilai koefisien regresi dari variabel (b) panjang cangkang sebesar 13,97 yang bertanda positif menunjukkan terjadinya pengaruh positif panjang cangkang terhadap berat basah daging, semakin panjang ukuran cangkang maka semakin bertambah pula berat basah daging sesuai dengan pertumbuhan dan pertambahan panjang cangkang. Selanjutnya nilai koefisien korelasi $\mathrm{r}$ berkisar 0,975 yang berarti menunjukkan besarnya pengaruh panjang cangkang terhadap berat basah daging yaitu sebesar 97,5\% dan sisanya 2,5\% berat basah daging yang dipengaruhi oleh variabel lain selain panjang cangkang (Irianto, 2004).

Menurut Komala et al., (2011) bahwa berdasarkan grafik hubungan panjang dengan berat kerang Anadara granosa didapatkan nilai koefisien korelasi (r) sebesar 0,58, sedangkan kerang Anadara antiquata berdasarkan perhitungan didapatkan pula nilai koefisien korelasi (r) sebesar 97, hal ini berarti hubungan panjang dengan berat kerang Anadara antiquata pada zona 3 adalah sangat erat. Menurut Ramanda (2014) bahwa berdasarkan Gambar hubungan panjang cangkang dengan berat kering daging Contradens contradens didapatkan nilai koefisien korelasi (r) berkisar 0,875 yang berarti menunjukkan besarnya pengaruh panjang cangkang terhadap berat kering daging yaitu sebesar 87,5\%. Hal ini juga menunjukkan bahwa pensi yang berada di Danau Maninjau dan di Sungai Batang 
Antokan memiliki hubungan yang sangat erat antara panjang dengan berat basah daging. Berdasarkan uraian diatas, maka dapat dikatakan bahwa hubungan panjang cangkang dengan berat basah daging saling mempengaruhi yang memiliki korelasi dan keterkaitan yang sangat erat antara individu kerang yang didapatkan dengan dimensi ukuran yang diperoleh.

\section{KESIMPULAN}

Dari hasil penelitian yang telah dilakukan mengenai Karakter Morfometrik Pensi (Corbicula moltkiana Prime) Pada Dua Ekosistem Yang Berbeda, maka dapat diambil beberapa kesimpulan antara lain sebagai berikut:

1. Sebaran ukuran panjang cangkang, tinggi, lebar, panjang hinge, jumlah garis pertumbuhan dan berat basah daging pensi di Sungai Batang Antokan lebih bervariasi jika dibandingkan dengan yang di Danau Maninjau.

2. Ukuran panjang cangkang pensi di Sungai Batang Antokan berbeda dengan ukuran pensi yang berada di Danau Maninjau sementara lebar cangkang dan berat basah daging tidak berbeda antaradua habitat yang berbeda.

3. Hubungan antara panjang dengan berat basah daging di Danau Maninjau dan di Sungai Batang Antokan mempunyai korelasi yang sangat erat dengan ukuran panjang cangkang kerang.

4. Faktor fisika kimia air di Danau Maninjau dan di Sungai Batang Antokan masih dalam kisaran normal dan sangat toleran dalam mendukung kehidupan pensi (Corbicula moltkiana Prime) kecuali kadar organik subtrat.

\section{SARAN}

Berdasarkan penelitian yang telah dilakukan mengenai pensi (Corbicula moltkiana Prime) ini disarankan untuk penelitian lanjutan mengenai bioekologi dan karakter reproduksi pada ekosistem sungai guna usaha budidaya agar kerang ini tetap ada.

\section{DAFTAR PUSTAKA}

Dermott, R.M. 1985. Benthic Fauna in Series of Lake Displaying and Gradient of pH. Hidrobiologia 128: 31-38. 
Irianto, A. 2004. Statistik, Konsep Dasar, Aplikasi dan Pengembangannya. Prenada Media Grup, Jakarta.

Komala, R.F., Yulianda, D., Lumbanbatudan I., Setyobudiandi. 2011. Morfometrik Kerang Anadara granosa dan Anadara antiquata Pada Wilayah Yang Tereksploitasi Di Teluk Lada Perairan Selat Sunda. Jurnal PertanianUMMI. Volume 1 Nomor 1.

Kordi, M. G. H. 2011. Budidaya 22 Komoditas Laut (Untuk Konsumsi Lokal dan Ekspor). Lily Publisher: Yogyakarta.

Michael, P. 1998. Metode Ekologi Untuk Penyelidikan Ladang dan Laboratorium. Penerbit Universitas Indonesia, Jakarta.

Ramadhani, A. H, M., Affandidan B., Irawan. 2011. Keanekaragaman dan Pola Distribusi Longitudinal Kerang Air Tawar Di Perairan Sungai Brantas.Jurnal Ilmiah Biologi. Prodi S-1 Biologi, Departemen Biologi, FST. Universitas Airlangga. Surabaya.

Ramanda, Riri. 2014. Studi Populasi Kerang Contradens contradens (Lea, 1838) Yang Terdapat Di Danau Singkarak Kabupaten Solok. Skripsi. STKIP PGRI Padang.

Safrinsyah, Dedi. 2010. Ilmu Tanah (SOIL SCIENCE): Sifat Kimia Tanah. (http://dsafriansyah.blogspot.com/2010/04/sifat-kimia-tanah.html. diakses 05 maret 2015).

Suwignyo, S. Widigyo, B, Wardianto, Y, Krisanti, M. 2005. Avertebrata Air, Jilid 1. PenebarSwadaya: Jakarta.

Zeswita, A.L. 1999. Habitat dan Kepadatan Populasi Serta Kebiasaan Makan Pensi (Corbicula moltkiana Prime). Thesis. Pasca Sarjana. Universitas Andalas Padang. 